\title{
Selling Hope: Gambling Entrepreneurs in Britain 1906-1960
}

\author{
Carolyn Downs, Lancaster University
}

\section{December 2014}

Send correspondence to Carolyn Downs, Department of Management Learning and Leadership, Lancaster University Management School, Lancaster University, Bailrigg, Lancaster, LA1 4YX. Telephone: +44-1524-510939, Email: c.downs@lancaster.ac.uk

Many thanks to Dr. June Cotte and Dr. Catherine Prentice for editing this special issue, and to the two anonymous reviewers of this article, whose input was extremely helpful in developing the paper. 


\title{
Se lling Hope : Gambling Entrepreneurs in Britain 1906-1960
}

\begin{abstract}
This research explores historical perspectives on gambling amongst poorer social groups in order to better understand why the poorest people in society gamble even though gambling seems economically illogical. A principal finding was that pleasure gained from hope of a small win and the agency of making a choice on use of scarce resources may be important in helping poorer people maintain optimism in the face of difficult life circumstances. The paper also explores patterns of illegal gambling entrepreneurship that arose as a response to the desire of the masses to "buy a few days hope" (Orwell, 1937). The paper concludes that where public opinion is out of step with the statute book then an illegal economy will develop to provide the goods or services the public is demanding and that apparently irrational behavior may in fact be a positive experience for many people.
\end{abstract}

Key words: Gambling, Enterprise, Entrepreneurship, Social Class, Poverty, Hope. 


\section{Selling Hope: Gambling Entrepreneurs in Britain 1906-1960}

\section{Introduction}

The history of commercial gambling stretches back centuries (Clark, 1983; Chinn, 1991; Clapson, 1991; Munting, 1996; Downs, 2008), but in many jurisdictions the commercialization of gambling took place in the illegal economy. In the United Kingdom (UK) lotteries were outlawed in 1823, and cash betting was banned in 1906. Despite some amendments allowing the football pools (1928) and charity lotteries (1934) most cash gambling remained illegal in the UK until January $1^{\text {st }} 1961$. Nevertheless, a substantial market for gambling games existed. Sociologists at Mass Observation (1947) found 68\% of all respondents reported gambling on the football pools, betting or lotteries in the past year. Kemsley and Ginburg (1951), reporting to the Home Office, found a combined (male and female) prevalence rate of $70 \%$ for these types of gambling. These prevalence rates are analogous to recent studies of gambling participation around the World (Binde, 2011). This suggests that even when most gambling is illegal participation rates in gambling are remarkably stable across time.

Participation rates in gambling are of interest in business and consumer research because while gambling is now legal in many jurisdictions it is not unproblematic; gambling is treated as a vice rather than legitimate leisure. Negative views of gambling are commonly held. A study of gamblers found $51 \%$ believed gambling to be 'generally addictive' and 56\% thought it 'a waste of money.'(Griffiths and Bingham, 2002) Gambling has the potential to cause harm, not just the addiction of an individual, but to family and wider society through debt and crime associated with excessive consumption (Downs and Woolrych, 2009, 2010; Smith and Wynne, 1999; Gazel, Rickman and Thompson, 2001; Korn, 2000). However, a significant 
commercial gambling sector developed between 1906-1960 leaving legislators to react to a de facto gambling industry rather than proactively regulating gambling.

This paper will consider the development of commercial gambling in the UK before January $1^{\text {st }} 1961$ when gambling was legalized. Entrepreneurs in the illegal economy succeeded through the exploitation of environmental and situational factors (poverty and the need for hope) that meant gambling supported the consumption preferences of working class consumers. The historical perspective helps in understanding the complexities of gambling consumption revealed in contemporary gambling prevalence studies which consistently show poorer social groups to have surprisingly high prevalence and addiction rates (Wardle, Moody, Spence, Orford, Volberg, Jotangia, Griffiths, Hussey and Dobbie, 2010), and illustrates how 'taste [in consumption] is socially and historically constructed and reveals in individual's position in the social hierarchy' (Saatcioglu and Ozanne, 2013). The paper explores the role of hope in the development of patterns of gambling consumption and the ways in which legal and illegal entrepreneurs of gambling were able to exploit the need for hope amongst a substantial proportion of working class consumers. It will show that, for working class gamblers, commercially provided gambling was an unremarkable and persistent part of their leisure lives whether the gambling was provided in the illegal or legal economy. Evidence comes from archival sources including Mass Observation Archive (MO), Parliamentary Papers (PP), autobiographies, collections of letters and the press.

\section{Background}

Rojek defined consumption as 'voluntary, monetary acquisition of goods and services in [a] market society' (Rojek 2006: 475). The link between leisure and consumption is unremarkable nowadays, though it is a far cry from the calls for rational recreation that ran through the $19^{\text {th }}$ and much of the $20^{\text {th }}$ centuries (Bradley, 1976) and which impacted on the 
respectable working classes use of leisure (Hoggart, 1957; McKibbin, 1998). Rojek (2006) argues that different social groups have a relationship with the market, the media and the state directly linked to their positioning in society, and this relationship impacts on their consumption of leisure. Rojeck states consumers are, 'positioned in relation to scarce economic, social, political and cultural resources’ (Rojek, 2006:10) and therefore do not have the capacity to make truly free choices about their patterns of consumption. Similarly, Saatcioglu and Ozanne found 'taste is socially and historically constructed and reveals an individual's position in the social hierarchy' (Saatcioglu and Ozanne, 2013:693). This is an important point regarding leisure choices. An individual's position in society may make adoption of the apparently irrational and potentially dangerous pursuit of gambling more understandable and perhaps even difficult to avoid for some poorer people. The process of the legitimation of consumption was shown by Ger and Belk (1999) to be linked to cultural variations in ethical thinking, similar to those found both within the British working classes, and between social classes (LeMahieu, 1988; McKibbin, 1998).

One of the unseen consequences of poverty is the impact it can have on an individuals will to act, 'Severe poverty demoralizes people when it erodes their sense of control.'(Myers, 2000: 329) but as Orwell noted, 'above all there is gambling, the cheapest of all luxuries. Even people on the verge of starvation can buy a few days hope ('Something to live for', as they call it) by having a penny on a sweepstake (Orwell, 1937: 87). The lack of day-to-day control over many elements in the lives of poorer people may heighten the importance of optimism and hope in the lives of people living in difficult circumstances. Gambling as a source of hope for poor people is not a new phenomenon, it was observed by social reformer Florence Bell, (1907) and sociologists B.S Rowntree, (1901, 1941) and Ferdynand Zweig (1948, 1952, 1961). Contemporary studies come to similar conclusions; 'Most people on low incomes dream of winning the pools or the National Lottery.'(Kempson, 1997: 8) Casey 
found that poor women in her study of lottery play 'were motivated by the prizes that they occasionally won,' and that day-dreams about winning were important in their daily lives (Casey, 2003: 253).

The persistence of gambling amongst poorer people may point to an 'enduring subculture, more at ease with chance and contingency, less committed to a faith in human mastery over fate, than the dominant culture of enterprise, efficiency and control' (Lears, 1995: 8). Although social commentators may see gambling amongst poor people as reckless disregard for money what is not so readily recognized is that where the amount of disposable income is small then saving makes little difference. Gambling may offer hope for the future and a degree of happiness (adrenaline, thrill of a win or near win, company, and the status of daring to place a scare resource on validating an opinion) during the experience. The economic logic of gambling, in terms of hope and happiness, may be weighed by the low-income nonproblem gambler against moral disapproval of gambling by peers or wider society, and in many cases moral disapproval loses. If gambling is seen as a bridge to lifestyle desires and enough people are reported as having made it over that bridge, hope of winning will survive in the lives of poorer people who gamble, for 'desire [is] deeply linked to the social world, both through the mimetic process and through the pool of available values systems and lifestyles that constrain the freedom to desire’ (Balk, Ger and Askegaard, 2003: 328). Thus, non-problem gambling amongst the poor may offer hope for a better future. This is reinforced by knowledge of life-transforming wins received by people like themselves while disappointment from not winning is mitigated by playing again.

Seligman and Schulman (1986) found that people with an optimistic explanatory style felt more in control of their lives and were protected from feelings of helplessness, even when facing obstacles or difficulties in life. Furthermore, they were less likely to suffer from 
depression than those with a pessimistic explanatory style. Abramson et al (2005) used a gambling task to measure levels of optimism. The game was computer-based and uncontrollable. Optimistic participants showed an illusion of control, often talking to the computer as though words of encouragement might persuade the random event to occur. This behavior will resonate with those who have observed players muttering 'come on 20' under their breath as they wait for the last number on their bingo card to come up. The optimistic group believed their skill and ability helped them achieve success at the task (Abramson, Alloy, Hankis, Clements, Zhu, Hogan and Whitehouse, 2000: 85). The finding that illusory control positively effects psychological health was replicated in a series of studies conducted as part of the long-term Temple-Wisconsin Cognitive Vulnerability to Depression (CVD) project. Concluding that 'even when optimism is illusory it provides protection from depression' (Abramson et al, 2000: 86) they noted optimism was a good predictor of resilience to depression.

For poorer gamblers it may be that leisure gambling, with a demarcated budget, offers an environment where a stressor can be experienced and controlled and this could be an important motivator to gamble. Psychologists find that a key ingredient for hope (optimism) is agency. Therefore it follows that hope is a thinking process, with outputs of thought being tools to finding paths to desired goals. As agency is not easily obtained by poor and powerless people it is perhaps not surprising to discover that poorer people are more likely to suffer from depression (Patel, 2008). Significant numbers of poor people participate in routine gambling and evidence from archives and in more recent work (Casey, 2003) shows routine gambling provides hope, encourages optimism, assists with goal achievement and gives pleasure, 'because, like, when you're skint you think, just put a pound in and get twenty quid' (Casey, 2003: 251). While lottery jackpots are elusive, and people realize they are unlikely to win a large prize, they do experience enough small wins to stoke up the hope of 
winning a larger prize one day. The belief in winning keeps them optimistic and purchasing tickets; for 'to make desire real people use consumption’ Belk et al, 2003: 329). The advantage of regular gambling with small amounts of money is that the dream of winning can be repeated over again with another stake, and the likelihood of regular small wins that make an appreciable difference to a tight budget is also well-understood by poorer gamblers (Hilton, 1937; Casey, 2003).

\section{Gambling in Working Class Society 1906-1961}

The disreputable nature of gambling as a vice was buttressed by prohibitive legislation. Laws to control and contain off-course betting, lotteries and sweepstakes were passed in 1823, 1845, 1856, 1906, 1934 and 1956 leaving most commercial gambling in the black economy until the Betting and Gaming Act (1960). The legal situation with gambling in the UK was closely tied to moral objections to the pursuit. Of most concern regarding gambling was the impact on the 'poorer sort' (Metropolitan Police Files, 1939, Public Records Office [PRO] MEPOL 3/765). The contention was that gambling led to secondary poverty, a trope widely understood and propagated. Other concerns were that gambling encouraged undesirable social characteristics such as a desire to get something for nothing, greed, laziness, crime and social disorder (Rowntree, 1905). Religious objectors to gambling, represented by the Churches Council on Gambling, an organization mainly comprising the non-Conformist Protestant churches plus evangelical Anglicans (Episcopalians), argued that gambling weakened trust in God to provide for all human needs; placed superstition over faith, undermined the Biblical command to work and encouraged greed which was a sin (Rowntree, 1905). However, other Christian groups were less opposed to gambling, The Bishop of Southwark, Monseigneur Cyril Cowderoy (1905-1976), articulated the position of the Catholic Church thus: 'Betting is not wrong in itself, neither is it wrong to play for stakes, 
even large stakes, providing the players can afford it and the game is not vitiated by circumstances that would make it wrong' (The Times, 9 Mar 1950:3). Despite the openminded approach of the Catholic Church and some liberal Anglicans the prevailing opinion of the authorities and most of the media in the period under consideration was that: 'Their [working class] culture was degenerate and inferior. Their resort to gambling might have been understandable, but it was still grossly irrational' (Dixon, 1991:42). The authorities therefore felt access to gambling by the working classes should remain restricted for their own good. This chimes with the assertion that 'acting on desires is seen to involve socially and personally dangerous consequences, including immorality' (Ger et al, 2003: 337) and that for the working class the potential dangers of gambling were considered to be outweighed by the 'cultural socialization of desire'(Ger et al, 2003: 344). The authorities wanted to control working class gambling because it indicated a willingness to believe in the powers of chance as a means of escape from poverty; the poor should not flirt with the addictive. In attitudes towards gambling the working classes cannot be seen as a cohesive unit, the significance of non-conformist religion and the role of respectability (almost a secular religion) must be taken into account when deciding how to approach archive evidence. Respectable, often chapel-going, sections of the working classes, many of whom were active in the trade union movement and Labour Party saw themselves as very different to those they considered less respectable; those who frequented the pub and were ready to wager their last sixpence rather than use it in the gas meter (Rowntree, 1941: 401). The respectable working classes feared wider working class gambling because it could lead to a fall from the respectable to the disreputable.

The legal status of gambling during the inter-war period was complicated with football pools (legal after 1928) still having regular brushes with the law up to the 1950s (Laybourn, 2007). Some small lotteries were allowed under legislation passed in 1934 but participation in 
the Irish Hospital Lottery was certainly illegal as was off-course cash betting and on-course totalizer betting. The great majority of illegal gambling was amongst the working classes, as the middle classes 'rarely betted' (McKibbin, 1998: 371). Britain in the period 1918-1951 has been described as 'one of the most working class countries in the world' (McKibbin, 1998: 106), with almost $75 \%$ returned as working class in the 1939 census, declining to $72.19 \%$ in the 1951 census and only a small decrease in numbers of working class by 1961 (Marsh, 1965: 224). Despite most gambling being illegal social observers of the inter-war period often commented on the prevalence of gambling amongst the working classes. Liverpool Women's Aid found in 1926 that 'Fifty percent of women have the betting habit' (Chinn, 1991:171) and a study in York concluded; 'A vast number of men and women indulge in this form of amusement' (Rowntree, 1941: 400). The Mass Gambling report observed that those who filled in pools coupons were 'predominantly thinking in terms of winning' (MO, 1948: 102). Rowntree's work provided a unique insight into the role of the pools as families sat together on Thursday evenings and decided the permutations for the coupon. He also detailed the pleasure gained as they planned how any winnings might be spent (Rowntree, 1941: 425429). The pools did provide a very real hope of winning, for apart from the winners of large prizes many people won a small amount on a regular basis (Hilton, 1936; File Report 2560). Pools wins were widely reported, commented on in popular culture, including songs, and became part of urban mythology (Downs, 2008).

Bell and Rowntree independently concluded that gambling amongst the poor was a rational choice, albeit one which they, both staunch anti-gamblers, could not approve; 'Every now and again a working man does win, and thereby acquires in one moment a lump sum of capital that would be accessible to him in absolutely no other way' (Bell, 1907: 260). The Pilgrim Trust study of unemployed men in Liverpool in 1938 found cash betting was allpervasive. 'Betting offers... the only possibility of making a decision, of a choice between 
alternatives, in a life otherwise prescribed in every detail by poverty and necessity, and always the object of other people’s decision'(Pilgrim Trust, 1938). The overwhelming conclusion of much social research into gambling during the period under consideration was that it was largely beneficial. Small wins provided necessities such as food and shoes, the time spent discussing form, deciding how to place a bet or which choices to make on the penny pools coupon gave men companionship and significant social status; winners were well-respected in their communities, people whose opinions "on very different matters are heard with respect” (Pilgrim Trust, 1938: 99). A bookies wife in 1947 said:

What else have they got to look forward too? They would never hope to get out of their rut, only with a little bit of luck they hope to find in gambling. You'd be surprised if you knew how heavily and regularly the working man bets. It's his kind of religion - it brings him some hope (MO, 1947:37).

Belief in winning was not unreasonable; reports of gambling wins of over $£ 100$ amongst family, friends or acquaintance were followed up by Mass Observation (1947). They found, 'Whatever social circles he moves in anyone ... is likely to have met one or two one-time winners of substantial sums' (MO, 1947:50). Thus, the consumption of gambling products in a generally manageable way was a rational means through which poorer people might improve life; the model of the Cycle of Desire (Belk et al, 2003: 344) can be well-applied to the experience of working class gamblers before 1961 who were seeking to improve their lives by the addition of hope or through a cash win. 


\section{Selling Hope}

The notion of working-class entrepreneurs of gambling may appear the antithesis of the history of the working-classes set out by E.P. Thompson (1963). Marxist historiography would surely not have room to allow for a form of capitalism to develop and thrive within the class most exploited by capitalists to provide the means of production? Indeed, perhaps it might be argued that any working-class entrepreneur making a living from providing gambling opportunities to his or her peers was a class traitor. Yet with gambling entrepreneurship things are perhaps not quite as straightforward as they appear. The working classes can be seen as living in a 'self-contained social world' (Ehrenreich, 2001:194) so that, even amongst the respectable working classes, strongly-held moral objections to gambling were balanced by a working class solidarity that saw the illegal bookmaker as part of the community, and resented the interference of do-gooders seeking to limit through legislation the legitimate leisure pursuits of a large section of the community (Chinn, 1991: 172; Steadman-Jones, 1983: 196-9). Thus, even those of the working class who did not gamble, were by and large not prepared to condemn the gambling of their neighbors.

Gambling entrepreneurship amongst the working classes sits well with notions of cultural materialism formulated by Thompson (1963). This allows for the autonomy of working class culture, and in such a context the development of working-class entrepreneurs of gambling could be viewed as a defense of working-class freedom to continue to gamble rather than an exploitation of working-class vulnerabilities from within. Gambling entrepreneurship also fits with Gramscian notions of hegemony which allow room for class agency and the development of culture from below while those within the dominant class develop channels through which they can subordinate and control the activity through institutions and 
regulation, arguably the pattern with commercial gambling (Gramsci, 2000). It is certainly the case that within working-class cultures 'sub-political' attitudes towards crime have always existed (Thompson, 1980: 64) which would explain the readiness of large numbers to provide illegal gambling opportunities or to break the law by participating in gambling. Where gambling is concerned distinctions between legal codes set down by parliament and popular notions of right and wrong have not always correlated: this disjuncture is important in seeking to understand the place of gambling entrepreneurship in working-class society and the place of some entrepreneurs of gambling as leading members of their working class communities (Chinn, 1991, Clapson, 1991). There was a symbiotic relationship between the popularity of gambling in working class communities and the provision of opportunities to gamble within the community. Often the local bookmaker was an important local figure, providing access to a phone, and Christmas parties for local children as well as employment for runners and lookouts (Chinn, 1991; Clapson, 1991; Huggins, 2003; MO, 1947, 1948). A significant proportion of gambling was organized by and for women, such as the 'picnic' clubs of Worktown (MO, 1943), sweepstakes held in factories (Zweig, 1952) and women acted as bookmakers, tipsters and runners (Elizabeth Roberts Archive Mr N2L RSC 88/562).

J.S.Mill (1851) wrote an essay defending the right to gamble, he also defined entrepreneurs as characterized by the need to bear risks as well as to manage their business; a point useful when considering the development of gambling entrepreneurship (Tay, 1996). Risks of imprisonment or substantial fines were set against the need to attract punters, the amount of money that could be made was balanced against the level of fine likely to be levied, the chance of an effective police raid and subsequent prosecution was balanced against the benefits of a static venue that punters could attend over organizing gambling on the street or moving from place to place. A cost-benefit analysis was made including adequately bribing the police to assist the entrepreneur by notifying them of raids or setting in 
place arrangements to pay fines or provide an income for the family of imprisoned bookies runners (MO File Report 2545, section C, 1947).

In the case of commercial gambling entrepreneurship 'a large and sophisticated industry was constructed to meet the demands of the small bettor' (McKibbin, 1998: 372) and was well-embedded in working class society. Embeddedness (Granovetter, 1985) is recognized within entrepreneurship (Uzzi, 1997) as a significant factor in whether an enterprise is sustainable within its social setting. Amongst working-class entrepreneurs of gambling being part of the community was critical to success. An illegal business was only sustainable if consumers trusted the operator and supported the activities being undertaken.

Gambling in the illegal economy did facilitate money laundering or loan sharking, exacerbating turf wars. Police constables were bribed to ignore street betting and little, if any, tax was paid (Hughman, 1971; Dixon, 1996, 1996; Clapson, 1991; Chinn, 1991; Downs, 2009). However, estimating the levels of crime associated directly with illegal gambling entrepreneurship is difficult because evidence was not collected in an organized way at the time. Money laundering and loan sharking are categorized as revenue offences and are almost impossible to separate from the larger dataset. Turf wars took place between street bookmakers but are filed under disorderly behavior, assault or other types of offence against the person. Nevertheless, despite some high-profile cases linked to serious criminal activity most entrepreneurs of illegal gambling seem to have focused on providing a good service to their client base. Local communities often strongly supported providers of gambling. If a prosecution was brought they would turn up in court to show solidarity (The Times, 6 Sept, 1947: 14); fitting the assertion of Naylor that; 'Market-based crimes that serve the forbidden consumption desires of compliant members of polite society require the criminal entrepreneur to provide a steady supply of product' (Naylor, 2005: 19). 
Unlike traditional forms of investment-based business venturing during this period, which required access to capital in order to start up, gambling ventures needed nothing more than a notepad and pencil, knowledge of the game and a degree of self-confidence in one's ability to run the game so as to ensure punters trusted the organizer to pay and play. Thus gambling entrepreneurship undermines conventional societal expectations of capital, and therefore externally verified markers of social responsibility, such as saving or being considered creditworthy as a pre-requisite for establishing a business. The business model offered by providing commercial gambling was eminently flexible, with scope for a wide range of types and scale of organization. Gambling as a profitable side-line to a more legitimate business was common-place, with the legitimate business providing a cover for the gambling business but so too were gambling-only businesses (Chinn, 1991; Clapson: 1991; Beckwith, 1971).

The increasing commercial success of illegal bookmaking (and the development of the football pools) relied upon technological advance. By the early 1920s a female bookmaker's office contained the latest communication technology: 'Situated in the heart of the slums, [the office] was barely large enough to hold, in comfort, mother, three clerks, the telephones and the ticker tape (Dawson, 1962: 12). The wages paid by the bookmaker were also a not insignificant reason for the support these ventures gained amongst the people in the locality. In 1920s London Elizabeth Dawson's mother employed about twenty runners from her shop in the East end. All were paid a commission of $10 \%$ on takings; most runners would bring in twenty to thirty pounds each race day, and more if a big race was taking place. (Dawson, 1962: 64) There were good economic reasons to continue placing bets: 'Even in those days of sixpenny bets [c1926] ...daily winnings could amount to quite fantastic sums, and they often run into several hundred pounds’ (Dawson, 1962: 66). 
The emergence of national chains in music halls, cinema, tea shops, magazines, popular press, professional football and dance halls were a feature of the late $19^{\text {th }}$ and early $20^{\text {th }}$ century business environment, providing a diversified leisure industry. In 1923 these operators were joined by the football pools, which although illegal until 1928 rapidly made John Moores 'Littlewoods' brand a national institution. Moores was from a poor family with first- hand knowledge of widespread football gambling amongst poor men in particular. His experience of the place of gambling in working class society showed him that if he could develop a means of getting round the rules that prevented cash betting on football he could make a legal living out of gambling. John Moores introduced the first widespread football pools venture from his family home in Manchester in 1923, but rapidly moved to Liverpool, perhaps as a result of the strong anti-gambling sentiment in Manchester, which was reflected in vigilant police action. Printing coupons based upon pre-announced fixtures list in advance allowed punters to pay by postal order, so the gamble was not strictly made in cash. In addition, games of skill were not illegal; Moores argued that the pools required skill in order to predict whether the pre-announced match would be win-lose-draw, and that as this was not fixed odds betting but a prediction involving skill it fell outside of the 1906 legislation banning cash betting (Clegg, 1993, Laybourn, 2007). The business started badly, but by the end of the 1926-27-football season the pools begun to take-off across the nation. Football pools expanded to such an extent that in 1928 the government legalized the activity, against the wishes of the Football Association who felt that allowing gambling on the results of matches would bring the game into disrepute. The football pools were immensely popular; an estimated £30m annually was being gambled by 1934, mostly in 6 pence postal orders, while the pools promoters employed about 30,000 people, the majority of whom were women (Walvin, 1994, pp 126-28, Clegg, 1993). The popularity of this gambling game was such that other pools companies then became established so that by 1930 a competitive market in this 
type of gambling existed (Hunter, 2002: 15). This new type of commercial gambling rapidly attempted to sever any link to the disreputable and acquire a veneer of respectability by careful use of language; pools coupons, not betting slips; dividends, not prizes, for those investors skillful enough to pick the correct permutation of matches. The technique appears to have worked very rapidly: 'This popular pastime [wa]s accepted as an understandable attempt to alleviate the boredom and poverty of everyday life (Jones, 1973: 121). The pools companies were further boosted by the popular press and Pathe newsreels reporting of stories about winnings, an effective form of free publicity. Life-changing sums were won by people from poor backgrounds making great human interest stories.

The rapid rise of greyhound racing was contemporaneous with the pools. Belle Vue in Manchester opened in 1926 and started a boom in dog racing and associated gambling. Dog racing was not illegal, but the totalizer gambling that took place as an integral part of the activity was. Tracks were located in urban areas, allowing the working classes access to oncourse betting and tote gambling, with the average UK tote pool in 1931 around $£ 180$ thousand per year, of which the track operator kept 12\% (Leybourn, 2007, p. 182). A parliamentary inquiry in 1933 found 20 million attended dog racing each year (PP 1932-33 Hansard, House of Commons, vol. 247 c.1104-5). The police instigated a number of legal challenges to this type of gambling too, but operators responded by simply changing the format of the type of game in response to legal action (MO File Report 13 and 2995). However, by late 1933 most Greyhound racing totes had closed down under pressure from the law (PP Hansard, House of Commons, vol 247 col.1243).

Credit bookmaking was not illegal during the period 1906-1960 and the 1921 census recorded 2824 male bookmakers and 73 female. Numbers trebled by 1931, to 9330 men and 425 women (Huggins 2003: 72). These figures do not include many more bookmakers 
operating the widespread illegal cash betting enterprises. Mass Observation noted that almost every factory had its own bookies runner, and often several (MO File Report 2545, section C, 1947). An example of the level of income that could be generated for the entrepreneur willing to break the law is provided by the case of a north London woman who ran a cash betting business between 1933 and 1956 and employed, 'More than a score of bookmakers, paid more than $£ 5,000$ in fines over the period, [but] still managed to make a handsome living (PP 1955-1956 DXLIX Hansard House of Commons Debates, c. 2523). She regularly lobbied her MP for a change in the law relating to cash betting. Clearly, this unnamed constituent was adept an making the most of an opportunity, she was providing a service that the public wanted, offered employment opportunities to local people as bookies runners and balanced the risks of prosecution and fines against the profitable opportunities offered by gambling entrepreneurship.

The demand for illegal cash betting amongst the working classes remained high throughout the period under consideration here. Studies of factory workers by Mass Observation and the sociologist Ferdynand Zweig and by Mass Observation at Penguin Books describe the collecting of cash bets on the factory floor. Cash and betting slips were put in a clock bag (that recorded the time the bag was sealed to prevent cheating) with the bag passed on to a bookies runner. This was standard practice in many factories (Zweig, 1948, 1952; MO File Report 2545, section C, 1947). Workplace lotteries based upon pools results were commonplace, as were bingo games at lunch times and other gambling games taking place in work time. The Mass Observation Penguin Books study found that many employees used a 'bookies runner' yet, the observers noted, these were people who, although in work, sometimes struggled to make ends meet. Alongside illegal cash betting employees of Penguin Books were also gambling on the legal football pools, which provided opportunities for dreams of wealth, 'Just think...£263,000 for a shilling', 'If I won £2,000 I'd go to America. 
I'd spend it in 2 [sic] years. Charter my own plane.' (MO File Report 2545). Bookmaking was an attractive enterprise option for the housebound too. One elderly blind woman in Lancaster earned a good living as a bookmaker in the late 1940s and 50s. She used to leave her back door open, and bets were placed on the shelf by the door, a slip of paper wrapped round the stake (Elizabeth Roberts Archive Mr N2L RSC 88/562). She was never prosecuted for running the business because the local police constables all placed their bets with her.

One of the largest fines issued by a magistrates court for commercial bingo operating illegally in the inter-war years was the result of an investigation that took place in Peckham in 1939. The Metropolitan Police were concerned about the spread of illegal commercial bingo in this part of London, noting that: 'Since 1937 a large number of prosecutions for Bingo have taken place all over the Metropolitan Police Divisions. It is quite immaterial whether the prizes are in cash or food'(PRO MEPOL 3/765). In the Peckham area the police were aware of seven operators, of whom the most noticeable was Louis Hart, whose premises were on the High Street. Mr. Hart opened his bingo parlor in 1937 and had two previous criminal convictions were for organizing commercial bingo (PRO MEPOL 3/765). Woman Police Constable (WPC) Cross and Woman Police Sergeant (WPS) Stratton (both undercover) made the observations and were the main witnesses for the prosecution. WPS Stratton noted that: 'Many other similar establishments are operating in the neighborhood and I am of the opinion that if a severe penalty is imposed on Hart, say a term of imprisonment, this would have the effect of stopping both his and others activities' (PRO MEPOL 3/765). Between thirty and sixty players were observed at each of the sessions of bingo, which ran from 10am until 6pm daily and often a queue of people were waiting to join the game. Sergeant Stratton noted in her statement that the game was extremely popular, and played 'mostly by women of the poorer class' (PRO MEPOL 3/765). In Peckham the prize for most games was 1 shilling and 3 pence, but at 2 pm each day a 10 shilling prize game occurred, which attracted long queues 
of players: 'There are never less than thirty players, and often a full sixty, each paying one penny per game; 1 shilling 3 pence profit per game minimum. The games last less than two minutes.' WPC Cross estimated the profit per hour to be a minimum of $£ 117$ shillings and 6 pence, and this was corroborated by Mr Hart's cashbook which suggested that the bingo games run at the arcade netted $£ 40$ profit each week (PRO MEPOL 3/765). After two full weeks of covert observations uniformed police were called in to make the arrests. During the police raid the caller reassured the players: 'Don’t worry; they take your name to frighten you. It's only a summons and we can soon pay the fine'. Given that Mr Hart's previous fines amounted to less than one week's profits the deterrent nature of the legal processes as an attempting to control illegal gambling was obviously minimal. On this occasion he was not imprisoned as requested by the police, but was fined $£ 55$.

Thus, by the inter-war years gambling was a huge industry, despite it being largely illegal; 'It was thought by some to be the second largest [industry] in the country' accounting for some $£ 300$ - $£ 400$ million pounds annually (Jones, 1986: 36) . After the war the problems of controlling what was effectively a substantial commercial operation moved up the political agenda. The post-war era saw a huge diminution in levels of social deference, and public opinion as reported in mass circulation newspapers was generally in favor of an end to classbased restrictions on cash gambling. Where magistrates had been willing to convict people for illegal gambling before World War Two, they were far less likely to convict after the war. Sir Laurence Dunne (Chief Magistrate) commented on the difficult position of the police and magistracy, required to arrest and convict people taking part in activities broadly the same as the credit betting legally undertaken by some of the police and magistracy: 'These enactments can be stated quite definitely to be thoroughly unpopular, they are resented by the public, tend to corruption of the police who have to enforce them and produce extreme divergence of opinion among magisterial courts' (The Times, 18 Nov. 1949: 6). Sir Harold 
Scott (Commissioner of the Metropolitan Police) complained that although his 'K Division' made 577 arrests for illegal betting and gaming in 1948 this required 16,000 police manhours (The Times, 26 Oct. 1949: 8). This poor use of police time was compounded by the fact that enforcing the law led to 'Complaints of corruption, even though unfounded and often malicious, create an atmosphere of suspicion'(The Times, 26 Oct. 1949: 8). The lack of public support for police action against gambling made the job of enforcement difficult. Officers resorted to stratagems and subterfuges in order to outwit gamblers, but to little avail. The press were concerned that the law on gambling led 'To a mockery of justice comparable, on a small scale, to the attempt to enforce prohibition in America (The Times, 18 April, 1956: 4). The attitude of the magistrates was also ambivalent; after an annual fair held at Hackney in 1950 the magistrates heard a number of cases brought by the local police in connection with organizers of traditional fairground gambling games of shove ha'penny and Houseyhousey. The magistrate was clearly not convinced that any public interest was served by the cases being brought and commented, 'but there are hundreds of fairs all over the country where this is going on'. The police inspector giving evidence agreed with the bench and the defendants were fined 10 shillings each and released (The Times, 18 Sept. 1951).

As well as illegal cash betting a huge number of illegal lotteries were taking place. In 1954 this amounted to the equivalent of 'running one Irish Sweepstake each week' according to figures given in parliament (PP 1955-1956 CXCVI Hansard_House of Lords Debates, c.1302). Bingo is, strictly speaking a lottery, and the figures reported in Hansard included bingo alongside various sweepstakes. Illegal bingo was difficult to prosecute as the Betting and Lotteries Act (1934) which was intended to help charities, opened a loophole in the law that allowed the first really profitable forays into (illegal) commercial bingo. Seaside bingo stalls were commonplace from the 1920s (Bingham, 1990; Downs, 2010) and were prosecuted occasionally (Bingham, 1990) but under the 1934 legislation so long as the game 
was ostensibly for charitable purposes then gambling was legal. Operators easily exploited this loophole, making small donations of around $£ 10$ per week and keeping most of the profits. The authorities were aware that 'Many evasions were perpetrated and substantial profits made before the Small Lotteries and Gaming Act (1956) limited prizes to $£ 100$ and charitable profits to $£ 750$ ' (Economist, 24 June, 1961: 1347). The popularity of both illegal and charitable bingo amongst the working classes led Butlins and Warner's holiday camps to introduce the game as a charitable fundraiser in their holiday camps. The companies also actively lobbied the Home Office during the committee stages the Betting and Gaming Act (1960) to make gambling in members clubs legal, and also to insert a clause in the legislation that waived the 24 hour 'cooling off' period that non-holiday camp gambling clubs were obliged to enforce. The charitable bingo games held in Butlins holiday camps were extremely profitable; donations of around $£ 50,000$ per year were made to charities such as National Playing Fields association. Donations were reported both in the Butlins newsletter to campers and in the popular press such as the Daily Herald, the change in the law that Butlins lobbied for was extremely profitable to the company (Downs, 2010).

\section{Conclusions}

The archives show that significant numbers from poorer social groups regularly risked small amounts of money gambling, and even budgeted for this expenditure in the hope of a life-changing win. During the period 1906-1961 significant numbers of the working classes made a living from providing the means to gamble, as street bookies, bookies runners, tipsters, through commission on the sale of Irish Hospital Lottery tickets, by running sweepstakes or organizing bingo games. However, the move of football and greyhound-based gambling into the legal commercial leisure industry, employing the working-classes rather than the working classes developing their own opportunities for gambling-based 
entrepreneurship, marked the beginning of the end of widespread involvement of the working classes in commercial gambling entrepreneurship. Public opinion regarding gambling was out of step with the statute book in the first half of the $20^{\text {th }}$ century, resulting in a large illegal commercial gambling industry. The government response to the industry was post-hoc control, such as the unsuccessful attempt by Winston Churchill to impose a tax on lucrative illegal cash betting in the years 1923 - 1926 and imposition of legislation allowing the establishment of legal football pools in 1928 five years after they were established. Leisure time gamblers tend to view gambling as a minor vice rather than a life-enhancing activity, but the hope and agency provided by small-scale gambling may in fact play a very positive role in the lives of poorer people. Belk et al (2003) describe the cultural socialization of desire as a route for the commodification of hope. This finding could provide an explanation for the large numbers of the working class poor who have always gambled even when they cannot afford to do so. Perhaps the most unfortunate side effect of the legalization of the pleasure of the mass of the people in 1961 was that it paved the way for large leisure corporations who were able to commence the 'Brutal exploitation of [the] hope of the working classes for whom purchasing a Lottery ticket [or participating in any other form of gambling] is the only way that they imagine they can escape their subordinate position in capitalist society’ (Reith, 2002: 100). Life does not offer many consecutive rays of hope to the poor, but gambling, and the associated processes of imagination, desire, realization and frustration (Belk et al, 2003: 344) offers a package of happiness-inducing sensations that 'provides a subversive commentary on dominant social values' (Lear, 1995: 10) with the bonus that the game can be repeated over again, providing excitement, helping make sense of risk and adding color and hope to routinized lives. 


\section{References}

Abramson, L.B., Alloy, B.L., Hankis, C.M., Clements, L., Zhu, M.E., Hogan, W.G.

Whitehouse, W.G. (2000) ‘Optimistic Cognitive Styles and Invulnerability to depression’ pp 75-99 in Gilham (ed) The Science of Optimism and Hope, research essays in honour of Martin E.P. Seligman. Philadelphia: Templeton Foundation Press.

Beckwith, Lillian. (1971) About my Father’s Business. London: Hutchinson.

Belk, R. W., Ger, G., \& Askegaard, S. (2003). The Fire of Desire: A Multisited Inquiry into Consumer Passion. Journal of Consumer Research, 30(3), 326-351.

Bell, Florence Eveleen Eleanore Olliffe. (1907) At the Works: A Study of a Manufacturing Town. London: Edward Arnold.

Binde, Per. (2011) "What are the most harmful forms of gambling? Analyzing problem gambling prevalence surveys." CEFOS Working Papers 12 (2011).

Bingham, Roger. (1994) Lost Resort? The ebb and flow of Morecambe. Milnthorpe:

Cicerone.

Bradley, Ian. (1976) The Call to Seriousness: the evangelical impact on the Victorians. London: Cape.

Casey, Emma. (2003) "Gambling and Consumption Working-Class Women and UK National Lottery Play." Journal of Consumer Culture 3.2 (2003): 245-263.

Chinn, Carl. (1991) Better betting with a decent feller: betting, bookmaking and the British working class, 1750-1990. Hemel Hempsted: Harvester.

Clark, Peter. (1983) The English alehouse: a social history, 1200-1830. London: Longman. Clapson, Mark. (1991) A bit of a flutter: Popular Gambling in England, 1823-1961. Manchester: Manchester University Press.

Clegg, Barbara. (1993) The Man Who Made Littlewoods: the story of John Moores. London: Hodder and Stoughton. 
Cunningham, Hugh, Leisure in the Industrial Revolution, London, Croom Helm, 1980.

Dawson, E. (1962) Mother Made a Book. London: Bles Ltd.

Dixon, David. (1991) From Prohibition to Regulation:anti-gambling and the law, Oxford: Clarendon.

Dixon, David. (1996) 'Illegal Betting in Britain and Australia’ in McMillen, Jan, (Ed.) Gambling Cultures - Studies in History and Interpretation, London, Routledge, 1996, pp 86100

Downs, Carolyn. (2008) 'The Changing Face of Gambling: the Gambling Act (2005) and working class gambling cultures’ in eds J. Caudwell, S. Redhead, A.Tomlinson, Relocating the Leisure Society: media, consumption and spaces. Brighton: LSA Publication No. 101 Downs, Carolyn. (2009) A social, economic and cultural history of bingo(1906-2005): the role of gambling in the lives of working women. VDM Verlag, 2009.

Downs, Carolyn. (2010)"Mecca and the birth of commercial bingo 1958-70: A case study." Business History 52, no. 7 (2010): 1086-1106.

Downs, Carolyn, and Woolrych, Ryan. (2009) "Gambling and debt pathfinder study." Manchester: MMU Occasional Publications.

Downs, Carolyn, and Woolrych, Ryan. (2010) 'Gambling and Debt: The wider impact' Community, Work and Families Vol. 13, No. 3, August 2010, 309-326

Ehrenreich, Barbara (2001). Nickel and Dimed: On (Not) getting By in America, London: Granta.

Gazel, Ricardo C., Rickman, Dan S. and Thompson William N. (2001) "Casino gambling and crime: A panel study of Wisconsin counties." Managerial and Decision Economics 22.1-3 (2001): 65-75.

Ger, G., \& Belk, R. W. (1999). Accounting for materialism in four cultures. Journal of Material Culture, 4(2), 183-204. 
Gramsci, A. (2000). A Gramsci reader: selected writings, 1916-1935. London: Lawrence \& Wishart.

Granovetter, M. (1985). 'Economic Action and Social Structure: the problem of embeddedness’. American Journal of Sociology, 481-510.

Griffiths, Mark, and Carolyn Bingham. (2002) 'Bingo playing in the UK: The influence of demographic factors on play.’ International Gambling Studies 2.1 (2002): 51-60.

Hilton, John (1936) Why I go in for the Pools. London.

Hoggart, Richard (1957). The Uses of Literacy. London: Transaction publishers. Huggins, Mike. (2003) Horseracing and the British, 1919-39. Manchester: Manchester University Press.

Hughman, Peter. (1971) Most Unnatural: an inquiry into the Stafford case, Harmondsworth, Penguin, 1971.

Hunter, W.A. (2002) Football Fortunes, London: Harpenden.

Jones, Stephen G. (1986) Workers at play: A social and economic history of leisure 19181939. London: Routledge \& Kegan Paul.

Kempson, Elaine (1997) Life on a Low Income, York: Joseph Rowntree Foundation.

Kemsley, W.F.F \& Ginsburg, D. (1951) Betting in Britain 1949-1950. London: Central Office of Information, 1951

Korn, David A. (2000) "Expansion of gambling in Canada: implications for health and social policy." Canadian Medical Association Journal 163.1 (2000): 61-64.

Laybourn, Keith. (2007) Working-class Gambling in Britain C. 1906-1960s: The Stages of the Political Debate Lampeter: Edwin Mellen Press Ltd.

Lears, J. (1995). Playing with Money. The Wilson Quarterly 7-23. 
LeMahieu, D. L (1988) A Culture for Democracy: mass communication and the cultivated mind in Britain between the wars. Oxford: Clarendon Press.

Mass Observation (1948) Mass Gambling: a report prepared by Mass Observation, report no 2560, commissioned by the National League for Education Against Gambling. London: Mass Observation (1943) The Pub and the People, London: Faber and Faber McKibbin, Ross. (1998) Classes and cultures: England 1918-1951. Oxford: Oxford University Press.

Munting, Roger. (1996) A Social and Economic History of Gambling in Britain and the USA, Manchester: Manchester University Press.

Myers, D.G. (2000) ‘Hope and Happiness’ pp 323-337 in Jane E. Gilham (ed) The Science of Optimism and Hope: research essays in honour of Martin E.P. Seligman. Philadelphia: Templeton Foundation Press.

Naylor, Robin Thomas. (2004) Wages of crime: Black markets, illegal finance, and the underworld economy. NY: Cornell University Press.

Orwell, G. (1937) The Road to Wigan Pier, London: Victor Gollancz.

Patel, Vikram. (2008) 'Is Depression a Disease of Poverty?’ World Health Organization Regional Health Forum South-East Asia Region (Volume 5, Number 1)

Peterson, C 'Optimistic Explanatory Style and Health pp145-161 in Gilham (ed) The Science of Optimism and Hope, 2000

Reith, Gerda. (2002) The Age of Chance: Gambling in Western Culture. London: Psychology Press.

Rojek, Chris. (2006) "Leisure and consumption." Leisure/Loisir 30.2 (2006): 475-486. Rowntree, B.S. (1901) Poverty: A Study of Town Life. London: Longmans Green and Co. Rowntree, B.S. (Ed.) (1905) Betting and Gambling: a national evil. London: Macmillan. 
Rowntree, B.S. (1941) Poverty and Progress: a second social survey of York, London, Longmans, Green and Co.

Saatcioglu, B., \& Ozanne, J. L. (2013). Moral Habitus and Status Negotiation in a Marginalized Working-Class Neighborhood. Journal of Consumer Research, 40(4), 692-710. Seligman, Martin E., and Schulman, Peter. (1986) "Explanatory style as a predictor of productivity and quitting among life insurance sales agents." Journal of Personality and Social Psychology 50.4 (1986): 832.

Smith, Garry J., and Harold J. Wynne (1999) Gambling and crime in Western Canada:

Exploring myth and reality. Alberta: Canada West Foundation.

Steadman-Jones, G. (1983) Languages of Class: Studies in English Working Class History, 1832-1982. Cambridge University Press: Cambridge.

Pilgrim Trust (1938) Men Without Work. London: Pilgrim Trust.

Tay, R. S. (1996). Degree of Entrepreneurship: an econometric analysis using the ordinal probit model. Lincoln: Lincoln University Commerce Division.

Thompson, Edward Palmer. (1963) The making of the English working class.

Harmondsworth: Penguin.

Uzzi, B. (1997). 'Social Structure and Competition in Interfirm Networks: The paradox of embeddedness'. Administrative Science Quarterly, 35-67.

Walvin, John. (1994) The People’s Game, London: Allen Lane.

Wardle, H; Moody, A; Spence, S; Orford, J; Volberg, R; Jotangia, D; Griffiths, M; Hussey, D; Dobbie, F (2010) UK Gambling Prevalence Study 2010. Birmingham: Gambling Commission.

Zweig, Ferdynand. (1948) Life, Labour and Poverty, London: Gollancz. 
Zweig, Ferdynand (1961) The Worker in an Affluent Society. London: Heinemann.

Zweig, Ferdynand (1952) Women's Life and Labour, London: Gollancz. 